\title{
War, Violence and Women: \\ a Case Study of Syrian Civil War (2013-2014)
}

\author{
Samina Noor* \\ Islamia University Bahawalpur \\ Pakistan
}

Received 12.01.2016, received in revised form 09.02.2016, accepted 28.02.2016

\begin{abstract}
Some nations have been experienced domestic armed conflict and that made the central point of the most of the research in international relations. Civil wars have became the widely used synonym for armed conflict in the world. Syria has busted in its third year of civil war which killed thousands of people and displaced millions.War is an inevitable reality of the cruel patriarchal system of male domination to oppressed other race, nations and used sexual violence against women as strategic war head. The violence against women in Syria fetched gendered security issues in the framework of international relations. This paper analysis the violence against women (VAW) in Syria should be characterized as security issue which required consideration and intervention in any way. Civil war and violence against women (VAW) not a new thing in the contemporary world where we claimed to be as civilized. Women are usually disproportionately affected by armed conflicts. During armed conflict, women have raped, brutally killed not only to threat women but also as an instrument of genocide. This research paper based on the violence against women (VAW) in current Civil War in Syria.
\end{abstract}

Keywords: Civil Wars, Arm Conflict, violence against women (VAW), International Relations, Rape, UNHCHR (United Nations High Commissioner for Human Rights).

DOI: 10.17516/1997-1370-2016-9-4-733-744.

Research area: politology.

\section{Introduction}

Civil wars are usually taken as the internally state conflict, however it is difficult to differentiate wars, civil wars, armed conflict. But there is a general acceptance that all kinds of above would be more vulnerable to women and children. Elizabeth Cady Stanton wrote in her book "The History of Women Suffrage" in 1881, " the story of the civil war will never be fully written if the achievements of women are left untold". Indeed, women paid a huge price while their men lost in civil war on one hand who would never come back and bear the fully responsibility of the children on the other hand.

Ban Ki Moon, secretary general of the UN (United Nations) said on $6^{\text {th }}$ March 2009 in the International Herald Tribune, Sexual violence against women is a crime against humanity. Sexual violence against women during armed conflicts now becomes war crimes with the adoption of +Statute of the International Criminal Court in Rome on 17 July 1998 and passing of

(C) Siberian Federal University. All rights reserved

* Corresponding author E-mail address: sameena.noor786@yahoo.com 
UN Security Council Resolution no. 1820 on 10 June 2008.

Violence against women (VAW) during armed conflicts has a long dated history, and now have been taken as a security issue. Therefore, unfortunately, it's always been ignored by the world. What is different from the past, only the world has able now to have the statistical data of suffered women during any Civil War and simply threw out for the international attention to the issues, though practically failed to protect women during such conflicts.

Violence Against Women (VAW) is an endemic in our society. Violence against women can be characterized into the following kinds: Physical, Sexual, Economic, and Psychological violence without age discrimination. Women who beard violence also sulfured mental and health issues. Violence Against Women (VAW) not only hurt women, also hit generation badly. Violence Against Women (VAW) has spread like a plague, any country, nation, race, and region of the world.

From many years, Violence Against Women (VAW) has used as weapon during war time, and continues with its horrify tactics. Moreover, VAW also used as political strategy for the ethniccleansing of a particular community in country., During war conflicts and civil war, women also facing violence like sex slavery, rape, different kind of abuses, forcibly part of militant groups, and regimes, forced miscarriages, kidnapping, and diseases transmission. These types violence have become strategical part of the regimes and militant groups to destabilize the innocent civilian during arm conflict.

Women has suffered sometimes in biological and sometime psychological ways, but all hit women badly. During every war or armconflict, as men killed on large scale, women usually experience wide range of sexual violence and infected with contagious diseases like HIV/ AIDS and conceived illegitimate pregnancy due to rape. Every humiliated and shameful acts have been used against women to give massages to enemies.

The flare of Syrian Civil War appeared in 2011 in the wake of Arab Spring. Although, Soon germinated into blood shed between Assad regime and opposite militant groups. The situation has becomes worse day by day and is likely to go forward. Both insurgents and regimes have committed all kinds of War-Crimes including, murder, hostage, killing, abduction, detention, sexually harassment, rape.

The huge increase in War-Crimes and round about the 6 million displacement of Syrian, make the worse humanitarian crises facing the world today. The UN (United Nation), international, and regional communities are trying to settle down the issue, but the nothing to achieved. This study given a comprehensive picture of human wretched that has become timeworn in Syria.

This paper briefly examines different dimension of Syrian-Conflict in the framework of international relations. Following a comprehensive brief of the nature of the crises, and analysis of the violence against women (VAW) against women in Syria. The number of women casualties increasing during regime's shelling, Scud missiles, Chemical Weapons against civilian, as well as the retaliation of rebels also killing women. Thousand of Syrian women were subjected to detention, forced disappearances by regime forces in the name of investigate about militants. They detained women for long time of period with deprivation of their right of any contact with their families. The violence against women including sexual violence has used as a strategy to defeat the opponents from psychological perspective, making women the most worthy target during war conflicts. 


\section{Violence Against Women (VAW) and new security Debate}

For many decades, the patriarchal security doctrine of realism has been changed now. It has crossed traditional militarily security boundaries to social arenas. According to the arguments of those who against the traditional patriarchal security doctrine of realism, many unseen social issues are important than militarily issues which are also hazard to the citizens.

Wars have been and go on as a tool to enhanced national boundaries. The discipline of International Relations have considered the upshot of wars. And the role of gender as politically, socially, economically output during wars and ignore the masculine domination. Therefore Joshua Goldetein argue that the gender can be used to understand the gender role in wars and conflicts ${ }^{1}$.

Men has been linked to wars and conflicts since the power game start being irrefrangible and refrangible. Therefore, we cannot say easily that all men are responsible and beni fitters of wars. Some men would be vanquished as women suffered a lot as morally, socially, economically, and physically during wars and conflicts.

Moreover, realism claimed, in the framework of autonomy and anarchy military forces are the main influential key in international relations. Radical feminism has claimed that the sexual violence against women especially rape run on a threat to women security. The acknowledgment of rape as a security threat to women would be acceptance of war time rape as collective security threat to nation.

Violence Against Women (VAW) usually has been intimately documented during conflicts or all kind od wars. However, documentation on VAW not more often than that women are brutely treated during wars. VAW including rape and torture not a new from centuries. It has become a universal truth, the conquered or victor had a divine right to treated women as sex slaves and sexually assault as punishment their enemies and satisfy their sexual desires.

Since VAW especially rape has become more strategic during conflicts, its lead to prolonged psychological damage or death not for the victim but as well as for their families ${ }^{2}$. However, sexual violence is now taken as war crimes which is conducted by victors and rebels has condemn at international level. Sexual violence has been codified in the Geneva convention (1949) and Additional Protocols (1977), these treaties have some provisions especially for sexual violence against women ${ }^{3}$. Due to these treaties, the rape and other sexual-crimes offender has become accountable ${ }^{4}$.

Many rape stories has been documented during war conflicts. International media, activists, writers, and scholars have given attention to the rape stories during war conflicts. The Nanking's Massacre, also known as Rape of Nanking, when 250,000 to 300,000 people were killed, and 20,000 to 80,000 women were raped by the Imperial Japanese Army. Many stories have been documented on that genocide against women in Nanking. According to Takokoro Kozo, a former soldier of the Imperial Army in Nanking:

"No matter how young or old, they all could not escape the fate of being raped. We sent out coal trucks from Hsiakwan to the city streets and villages to seize a lot of women. And then each of them was allocated to 15 to 20 soldiers for sexual intercourse and abuse"s. Following the Second World War, about 1000,000 women raped by Red Army their invasion in 1945, they raped every women without any age discrimination ${ }^{6}$.

\footnotetext{
"According to one victim, Red Army
} came into our town, pointed their weapons at me and other two women and ordered us into the yard. In the yard twelve soldiers 
inturn raped me. Others soldiers also raped my two neighbours" 7 .

The Genocide of Bosnian Muslim never forgotable during 1992-96. The mass rape of Muslim women was a cruel and brutal act of the strategy of Muslim-Ethnic Cleansing in Bosnia. According to women from Bosnia:

"The White Eagles would come to get us every night. They would bring us back in the morning. There were nights when more than 20 of them came. That seemed to be some kind of honor. They did all kinds of things to us"s.

During conflicts women kidnapped for used as sexual slaves and for typical some household like to cook and washing cloth for them. Due to continually sexual intercourse with multiple men, women infected HIV/AIDS and other sexual transmitted diseases. During conflict in Democratic Republic of Congo (DRC), many stories had- been highlighted on media about women-buried alive by local people because they were suspected to provide assisted to rebels that the local people did not support.

Sexual violence has been used to punish the local who usually support opposite group. We could say that, it was a mass genocide of Tutsis. According to a victim from the village Mai Mai:

They came in the morning and raped me, two of them. That didn't disturb me so much after what happened later,» she said. «In the afternoon five men came into the house. They told my husband to put three kinds of money on the table: dollars, shillings, francs. But we didn't have any of that kind of money. We are poor. We don't even know what dollars look like. So they shot him. My children were screaming and so they shot them. After that they raped me, all of them»?.

The international media have been highlighted far-flung rape cases in Somalia, where every nine girls out of ten has been raped. According to a Somalian girl, her story published in a article:

"The girl's voice dropped to a hush as she remembered the bright, sunny afternoon when she stepped out of her hut and saw her best friend buried in the sand, up to her neck Her friend had made the mistake of refusing to marry a Shababcommander. Now she was about to get her head bashed in, rock by rock."You are next," the Shabab warned the girl, a frail 17-year-old who was living with her brother in a squalid refugee camp. Several months later, the men came back. Five militants burst into her hut, pinned her down and gang-raped her, she said. They claimed to be on a jihad, or holy war, and any resistance was considered a crime against Islam, punishable by death"10.

The nature of crises are vary country to country, but the canvas of VAW are similar. In countries like Bosnia, Somalia, Congo (DRC), Afghanistan, Sierra Leone, Palestine, Burma, Kashmir, and Syria, population have forced to flee and experienced horrible sexual-violence in their lives.

\section{Nature of The Syrian Society and Conflict}

The stories about the violence against women in Syria is not unpretentiously teles for virtuously documentation, it would be matter of security. Prior to the conflict, Syrian society was facing same fate of high rated unemployment, high inflation, less public political representation, 
and repressive regime security forces like other Arab countries. Together with, Syrian society is a religious sectarian (74\% Sunni \& 13\% Shia) and pocket-size non Muslim (10-12\%) and lingual divided society.

Above mention diagram, yellow Sunni Muslims represent the largest ethnic-sectarian group of Syria. Albeit, country is run by a minority group Alawites (Shiite). Bashar-alAssad and other members of this Alawites playing a pivotal role in the ongoing blood shedding in Syria. As well as only 8\% Kurds also have taken up arms against the regime for their rights (Fig. 1).

The Arab Spring- a series of Middle Eastern revolutions against ruthless cruel dictatorship, made space in Syria and a peaceful political protest has intensified into a blood shed civil war between rebel and regime. Un-pity cruel regime has responded to the

Assad's regime has responded to the insurgent with massive violence, even though he has been unable to crush the rebels. These insurgents is now availed capacity to strike over main cities of Syria like Damascus. These rebels backing financial and military by Middle Eastern Countries and some others big powers, and took control over North and East part of the country. Not exclusive victory of regime or rebel groups as can be seen, henceforth massive destruction, bloodshed, violence, displacement over innocent civilians. In short, we can say that there is no easy to sort out the conflict, because the peaceful protest that started against dictator now escalating towards ethnic and sectarian war. The fears between minorities like Christians and Kurds increase day by day.

Due to this civil war, the humanistic situation of Syria has perpetually intensified and fighting spread across the country. The current situation in parts of Damascus, Aleppo, Hama, Homs are becomes war-zones, where people have out of basic living needs ${ }^{11}$. According to UN official figures, round about 9.3 million Syrian has drastically suffered and need basic humanitarian assistance and every coming day adds to this number more. Together with this 6.5 million Syrian have been displaced within the country and 2.3 million in neighbour countries (Lebanon, Jordan, Turkey, Iraq, Egypt) make the

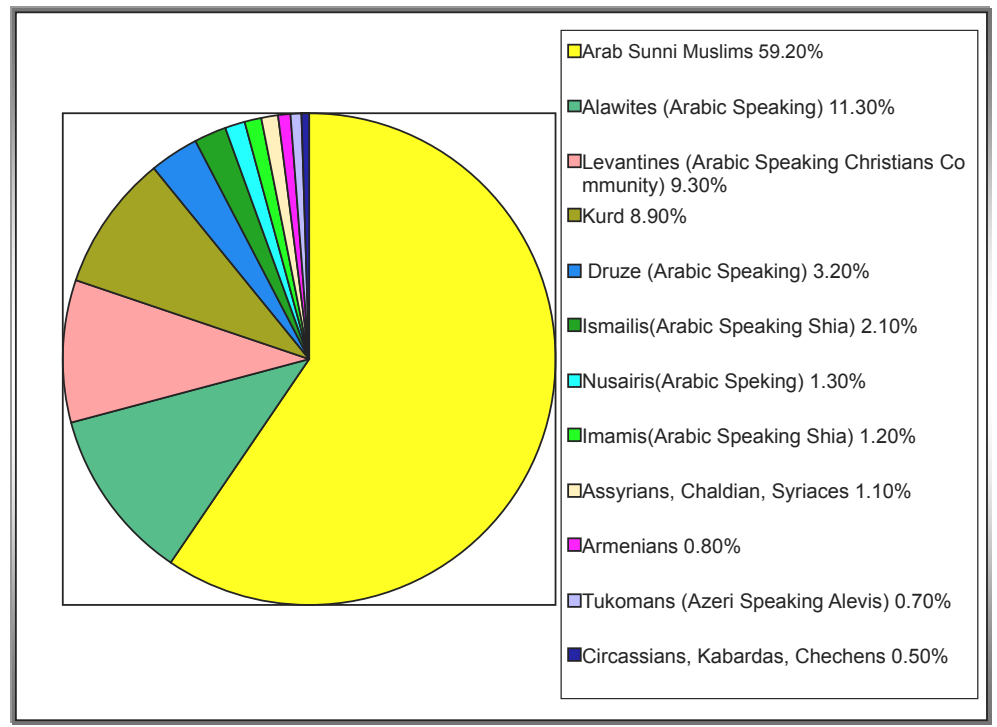

Fig. 1 
endangered situation especially for Women and children.

Many neighbour countries generously loose the border and provides shelter, foods and other basic needs for living for Syrian refugees, notwithstanding they are failed to managed the services and many incident took place on daily basis like abduction, detention, rape and sexual harassment. In unhygienic refuges camps, henceforth, they are suffered different kind of diseases due to unsafe drinking water, poor sanitary system, lack of food and medicines.

\section{Violence against women (VAW) in Syria}

The Arab World is socially, ethnic, racial, religiously, and nationally divided. Although the whole Arab World believed on women as a secondary being of the society in maledominated culture which opposed equality of both sexes. Comparatively other Arab Countries, Syrian's women condition has been changing to some extent during past few years. No doubt, in Muslim World wheres only the child bearing and house holding are the main functions of the women, Syrian has improved women position in state's economy due to the influence of liberal thought over women in past few years.

According to the Syrian constitution, all citizen would be considered equally without any sex discrimination. Regardless this constitution, the women badly suffered in Syrian patriarchal system, where women even can't travel alone due to matters of dignity. In Syrian-Patriarchy society, where women must have obeyed all the man-made rules and forced to bear all kind of discrimination, domesticsexual violence, sexual harassment, honor killing. And men never been punished for any crimes against women because, religiously, socially, and culturally permissions.
In Syria, millions of innocent people are struggling in sieged areas by violence and hideous for their lives. Its can not be easy to measured destruction and violence in the warfield of Syria where, situation getting worse at every coming day. Million of innocent Syrian are in dire situation and need humanitarian relief for their children and women. Million of Syrian have displaced due to combust of infrastructure by shelling between regimes and rebels. The civilian are bound to flee one place to another for shelter within or cross the borders.

In Syria, women and girls have been attacked publically and in their own homes by rebels and national army men. In society where modesty considered everything women raped in front of their own family members and also forced to act shameful things naked. Due to social values, such rapes never been reported by any survival to fear of recompense.

According to Euro Mediterranean Human Rights Network's issued report on Syrian Crisesatleast 6,000 Syrian have ben raped only in $2013^{12}$. Violence Against Violence (VAW) continue to be underestimated in unpredictable situation of Syrian society where women needs medical, morally, and psychological assistance. According to report, women and young girls bound to persists in perpetual fear of sexual violence.

In Syria, women are raping in detention, forced abduction, to keeping down their families, whose families were surmised to support opposite groups. VAW has been used as a maneuver to get the better of on psychological grounds, forthwith intense exaggeration of the conflict over moral aspects. The Euro Mediterranean Human Rights Networks (EMHRN) issues a report titled "Violence against Women: A Bleeding Wound in the Syrian Conflict" on International Day for the Elimination of Violence against Women 2013, that shows how sexual violence and torture has been heightened against women. 
EMHRN has conduct many interviews of victims of sexual violence in Syria. According to Kholod who belongs to Homs:

She said "During my detention, political security officer told me that he was holding 17 women prisoners in our home in Bab Al-Dreb neighborhood, He said they were abducted during the raids he carried out and that he raped all of them. When I asked about the crime that these girls committed, he said that he wanted to rape them and humiliate their families ${ }^{13}$.

Aida tells her story in that way to EMHRN's interviewer:

She said: "In the headquarters of raiding unit no. 215 of the military security apparatus in Damascus, they gathered all the girls and ordered them to take off their clothes, allegedly for inspection. They force-stripped everyone who disobeyed. The most irritating thing was the rolling camera recording what was happening» ${ }^{14}$.

On the name of investigation, how women are raping and brutely torture in Syria. Kinda not only raped, also lost her child due to miscarriage. when a women is subjected to rape and sexual violence, she experienced extreme emotional stress, where she has hyperbolized with guilt and humiliated and confined herself in dreadful world. In addition, due to that trauma, victim may go unswallowed by their family members. VAW has been seeding clouds in Syria, and drenched humanity, ethic and morality in tsunami of terror.

Each day, newspaper or news channels highlighted some dreadful stories, shows how women has been killed by their family member being averred to disgraced their family. The
UNHCHR (United Nations High Commissioner for Human Rights) has defined Honor Killing as:

"In the name of preserving family honor women and girls are shot, stoned, burned, buried alive, strangled, smothered and knifed to death with horrifying regularity" ${ }^{\prime 15}$.

Syria was never out of those Muslim countries where, women have been Slaughtered on the name of family honor. Therefore, the current civil war has induced the honor Killing because the increased in rapes, victims found they were denounced by their families, and their families has hesitate to accept them. Rolla Hallam has mention in her paper which she presented in an International Women's Rights Conference in London:

“ My dad is a gynecologist and he was referred an 11 year old and a 14 year old pregnant girl as a result of that, she said. Their fathers had threatened to kill them, and they had been abandoned by their families"16.

Child marriage is a common practice of Arab World as well as Syria. But the ongoing civil war has made the circumstances more grievous. Sutra marriages or marriages for protection has become a tool for the girl protection from any expected sexual threat from the regime and rebel powers. Parents or families who thought, they are unable to protect their daughters are marrying them off to defend them against rape, because they have no other choice.

Turkey and Jordan have become the main destiny of Syrian refugees. Al-Za'tri (Jordan) is uttermost deserts from the population with hot summar and gelid winters. Worst seasonal circumstances and lack of heath facilities makes 
the life impossible in these refugees camps for Syrian people especially for women and children. And the refugees camps in Turkey have the same fate.

A marriage mafia has been established in Al-Za'ri camps to made forced and supportive marriages for Syrian girls and women with the help of religious clerics. In these refugees camps Syrian women and girls just sold in only 100 or 200 dollars for lasting marriages.

According to a Jordanian man who looking for a girl for marriage:

"I told them i was looking for a wife.

"Go to the refugees camps" they said, because Syrian girls are almost for free"17.

According to Faruq Logoglu, the deputy chairman of the Turkish opposition party, many Syrian women and girls are being sold to Arab states $^{18}$. Syrian women and girls are trafficking to rich Arab state as sex slave, and these women and girls are forced to bear such brutality against their will.

In these refugees camps, many pregnancy have been seen by UN doctors. They were surprised, these victims are usually under age girls. These UN or others volunteer medical groups reported many teen suicide victims. According to a girl of 13 who was raped by a Turk military official:

"I bagged a Turkish military man not to rape me, since i was a Sunni like him, but he replied that i was a Syrian Sunni, and he was Erdogangi Sunni"19.

For migrants, executing daily life is strenuous. Since the civil war perpetuate, people have out of cash while cultivate multiple debts. Syrian refugees are incapacitated to attain work permits in Turkey, Jordan due ethnic discrimination. While there is no source of income, prices go up and up, refugees risk their lives in jam-packed with limited access to basic needs.

In Syrian patriarchic and religiously orthodox society, where women never been allowed to work, women refugees with less income resources totally helpless to make their basic needs ${ }^{20}$. The situation has became more sever in case of single and widows their male relatives are not available. Such critical living ways of life leads theme to prostitution, early marriages, and temporary marriages( Mutta) to fill the bill for themselves and their children.

For refugees camps are out of basic health facilities that leads to minimum chances of protection from diseases. At the same time, host countries offer many health facilities to the refugees, but that is not enough to comply with their needs. In these camps, women's condition are more critical since they need more sexual, reproductive and mental health services ${ }^{21}$.

In these refugees camps, women and girls has becomes the victims of rape and sexual violence and suffered many Sexual transmitted diseases (STD) and sexual transmitted infection (STI). Some contagious diseases also affected women, girls, and especially children in refugees camps. These camps also facing psychological mental issues on daily basis.

\section{Concern of International Community Over Syrian's Women Catastrophe}

The U.N. has given the numbers of people in needs of humanitarian assistance in Syria is 9.3 million, IDPs (Internally Displaced Persons) round about 6.5 million, and 2.2 million people has taken refugees in neighboring countries ${ }^{22}$. Security Council had been adopted the resolution 2139 in February, 2014 demanding back off against innocent civilian and pose no crippled to foreign assistance and aid to people ${ }^{23}$. 
Currently two coordinating funding appeals are going one is UN-Syria Humanitarian Assistance Response Plan led UN-OCHA (United Nation Office for the Coordination of Humanitarian Affairs in Syria. First appeal was called in July 2014 to revised aid from US $\$ 180$ million to US \$347 million. The Regional Refugees Respond Plane by UNHCR revised funding to US $\$ 197$ million $^{24}$.

Valerie Amos (United Nations Emergency Relief Coordinator) has alarmed the situation, 9 million desperate Syrians enticement in war zones without receiving any assistance outside ${ }^{25}$. She also motivated the world to do something for those who have been displaced in their own countries and neighboring countries. In 7 June 2013, Valerie Amos on the behalf of UN has made organization's history humanitarian appeal 4.4 billion US dollars to facilitate the Syrian people ${ }^{26}$.

According to UNFPA (United Nation Fund Population Agency), the increased in violence Damascus and other cities, which has forced thousands of women to flee across the border for safety. UNFPA's Executive Director Dr. Babatunde Osotimein told, UNFPA has tried to provide all possible assistance and aid to women and girls because they effecting badly on the based of their gender ${ }^{27}$.

According to UNFPA, estimated at least 2.3 million women and girls facing world biggest philanthropic impasse in Syria. The UNFPA has raised funds approximately 81 million dollars to provide health farcicalities for those women and girls ${ }^{28}$. The UNFPA also providing reproductive and pregnancy plus deliveries health facilities to women and young girls within Syria and refugees camps. Agency also going up against GBV (Gender Based Violence) in Syria because conflict raised the vulnerability of sexual harassment against women and young girls.
According to UNHCR( United Nations High Commissioner for Refugees) review of 2013, destruction of infrastructure, lack of economic and finance resources continue to sweep all the instability of traditional household in refugees camps ${ }^{29}$. Men as the head of the family simply can not afford the living expenses. Continues armed conflict then displaced, Powerlessness, and economic disabilities, leads them to further psychological and emotional turmoil more likely to increased domestic violence many women reported in refugees camps ${ }^{30}$.

The forced marriages has been increased within IDP communities due to absence of insecurity and basic living needs. So displaced and families within war zones forced to believed that early marriages is the only way to protect their women chastity ${ }^{31}$. The UNHCR also reported, sex trafficking within and out side Syria has been increased in form of unofficial marriages. The current Syrian regime has contrived to strict laws (Article 489) in 2013 to prevent women from sexual assault ${ }^{32}$.

The UNHCR had made effort to highlighted all the issues which facing Syrian IDPs and refugees through group discussion and voluntarily conducted visits to victims. Beside victims counseling, UNHCR also provides medical, psychological and financial assistance to many women there ${ }^{33}$.

The European Union is the biggest donor to provided assistance to Syrian people. Since 2012 the EU and its members have given $€ 230$ million, within and outside the country in the realm of medical, food, shelter and financial to those who affected by the civil $w^{34}{ }^{34}$ US has announced USA 380 million funding for Syria in 15 January 2014 under the slogan of "No Lost Generation". Total US \$ 1,739,769,523 financial aid has made by US for Syrian people. 


\section{Conclusion}

At last we concluded that war is intensively rooted in male dominated patriarchic system where women have to paid more as a symbol of dignity and honor of family. In patriarchal societies, where a rival male would be considered slander if he unbale to protect his women. During armed conflict or civil wars, women becomes the booty of every rival men. Women not only dishonored also rejected by their families and seclude from social ties.

In Arabic Middle Eastern patriarchic societies where children belongs to father rather than mother on religious perspective, rape has been used as a weapon of ethnic cleansing to balances the population of desire ethnic group. On religious and social grounds, pregnancies caused by rape never been accepted by women's families.

The aim of this article to analysis how violence against women especially mass rape during Syrian civil war become a continuers threat to women security. Sexual violence against women and girls directly related to warfare in conflict places where, rape used as a strategic tool which leads permanent threats, fear and humiliation being subjugation.

The break down of law and order and mass displacement gives rise to accelerate all form of violence against women. During conflict, incapacitation and minor role of traditional men leads further violence against women like domestic violence, early and force marriages.

No doubt, media, international organizations, NGOS have succeeded to achieved everyone's attention towards violence against women in Syria. Therefore, a great deal is remains to provide safety and assistance to women and girls in Syria and neighboring refugees camps. Syrian conflict has not only effected Asad's government, but also to innocent Syrian women and girls. Thousand of Syrian has dislocated within Syria and other neighboring countries for safety and peace.

Apart from sexual and psychologically ramification, violence against women during conflict also fallout the social health of Syrian community. Social fetter totally collapsed as women keep apart themselves or secluded by their families and communities Many victims of violence will never retrieve from psychological and physical trauma of these incidents and will die from them or some times kill themselves. Barbarism against innocent people and sexual violence against women has becomes indispensable part and parcel of Syrian Civil War. Since as the war is strive in Syria, women will remain vulnerable to be assaulted during civil war.

Goldstein,S., J. (2011). War and Gender: How Gender Shape the War System and Vice Versa. UK: Cambridge University Press. P. 2-11.

2 Sandara, I. (2011). Victims of Rap and Gendercide: All Wars. In Sandra, I., Eliatamby, I. (Eds.), Women Warming War and Peace: International Perspectives of Women's Roles in Conflicts and Post Conflict Reconstruction. (p.13). New York. America: Continuum International Publishing Group.

3 Women 2000. Sexual Violence and Armed Conflict: United Nations Response.Published to Promote the Goals of the Beijing Declaration and the Platform for Action April 1998. Retrieved 21 December, 2013 from http://www.un.org/womenwatch/daw/public/cover.pdf.

4 Treatment of Sexual Violence in International Law. Retrieved, 21 December, 2013 from http://www.iccwomen.org/resources/crimeschart.htm.

Geneva Conventions (1949) \& Additional Protocols (1977)

Common Article 3

This article, common to all four Geneva Conventions, applies to non-international armed conflicts and prohibited outrages upon personal dignity, in particular humiliating and degrading treatment against protected persons.

Article 27 of the Fourth Geneva Convention, relating to the protection of civilian persons in time of war, states: Women shall be especially protected against any attack on their honour, in particular against rape, enforced prostitution, or any form of indecent assault.»

Article 75 
Additional Protocol I, relating to the protection of victims of international armed conflicts, prohibits: outrages upon personal dignity, in particular humiliating and degrading treatment, enforced prostitution and any form of indecent assault. Art. 76 calls for special protection of women in armed conflict.

Article 4 of Protocol II, relating to internal armed conflict, prohibits: outrages upon personal dignity, in particular humiliating and degrading treatment, rape, enforced prostitution and any form of indecent assault.

5 Chang, Iris. (1998).The Rape of Nanking: The Forgotten Holocaust of World War II. Retrieved in December 25, 2013 from http://missaldrichenglish10.weebly.com/uploads/1/2/1/5/12156708/the_rape_of_nanking.pdf.

6 Beevor, Antony. (2000). The Fall Of Berlin 1945. New York: USA. Penguin Putnam, Inc. Pp,10-13. Ibid, p. 31.

8 Hirsch, Michele. (2012).Retrieved 28 December, 2013 from http://www.womenundersiegeproject.org/conflicts/profile/ bosnia.

Mirsada, aged 17, spoke to a women's group of her extreme abuse in a rape camp. Her story was printed in a 1993 Los Angeles Times article.

9 McGreal, Chris. (2006). Hundreds of thousands raped in Congo wars. Retrieved 28 December, 2013 from http://www. theguardian.com/world/2006/nov/14/congo.chrismegreal.

10 Gettleman, Jeferey. (2011). Retrieved 29 December, 2013 from http://www.nytimes.com/2011/12/28/world/africa/somaliafaces-alarming-rise-in-rapes-of-women-and-girls.html?pagewanted=all\&_r=0.

A version of this article appeared in print on December 28, 2011, on page A1 of the New York edition with the headline: For Somali Women, Pain of Being a Spoil of War.

11 Syria Crises.European Commission. Humanitarian Aid \& Civil Protection. Retrieved 7 December,2013 from http:// ec.europa.eu/echo/files/aid/countries/factsheets/syria_en.pdf

12 Euro Mediterranean Human Rights Network's Report issued 2013, Retrieve 15 December, 2013 from http://www.euromedrights.org/eng/2013/11/25/international-day-for-the-elimination-of-violence-against-women-violence-against-womenbleeding-wound-in-the-syrian-conflict/.

13 Ibid.

The interview was conducted in late Feb 2013.

14 Ibid. P. 15.

15 (2010). High Commissioner speaks out against domestic violence and «honour killing» on occasion of International Woman's Day». Retrieved 2 January, 2014 from http://www.ohchr.org/EN/NewsEvents/Pages/DisplayNews. aspx?LangID $=$ E\&NewsID $=9869$.

16 Batha, Emma. (2013). Syrian war causing 'honour killings', child marriages - doctor. Retrieved 3 January, 2014 from http:// www.trust.org/item/20131204182854-8hegf/.

17 Stoter, Brende. (2013, Nov 22). Teenage Syrian refugees wed 'for protection. Retrieved 10 January, 2014 from http://www. aljazeera.com/indepth/features/2013/11/teenage-syrian-refugees-wed-protection-201311101497543146.html.

18 (2013, Feb 20). Female Syrian refugees in Turkey being sold to Arab states: Turkish politician. Retrieved 10 January, 2014 from http://www.presstv.ir/detail/2013/02/20/289896/syrian-women-in-turkey-camps-sold/.

19 (2013, April 16). Syrian Refugees Women Murdered, Raped, Forced to Marry in Refugee Camps in Jordan .Retrieved 11 January, 2014 from http://jafrianews.com/2013/04/16/syrian-refugee-women-murdered-raped-forced-to-marry-in-refugee-camps-in-jordan-turkey/.

20 The Syrian Humanitarian Crisis: Raising the Profit of Women and and Girls. (2013). Care Action Now org. Retrieved 24 January 2014 from http://www.care.org/sites/default/files/documents/2013-syria-crisis-women-girls-brief.pdf.

$21 \quad$ Ibid.

22 Syria-Complex Emergency. (2013). USAID. Fact Sheet\#2Fiscal Year (FY)2014. Retrieved 3 February, 2014 from https:// scms.usaid.gov/sites/default/files/documents/1866/syria_ce_fs02_11-07-2013.pdf.

23 Humanitarian Needs Outpacing Amid Ongoing Obstacle to Aid Delivery in Syria-UN. (2014). UN News Center. Retrieved 2 June, 2014 from http://www.un.org/apps/news/story.asp?NewsID=48142\#.U7AL8ZSSxBQ.

24 Funding to the Syrian Crisis. (2012). Retrieved 3 July, 2014 from http://www.globalhumanitarianassistance.org/fundingto-the-syrian-crisis-3782.html.

25 World Must Do More' to Aid Besieged Communities in Syria, Urges Top UN Relief Official. (2014). UN News Center. Retrieved 2 June, 2014 from http://www.un.org/apps/news/story.asp?NewsID=46913\#.U7AVvpSSxBQ.

26 UN News Centre (2014).UN Announces Largest Ever Humanitarian Appeal for Conflict- Torn Syria. Retrieves 3 July 2014 from http://www.un.org/apps/news/story.asp?NewsID=45112\#.U7UM2ZSSxBQ

27 Ibid.

28 Press release, 13 January 2014, UNFPA Calla for More Support to Address the Special Needs of Syrian Women and Girls. Retrieved 18 June, 2014 from http://www.unfpa.org/public/home/news/pid/15933.

"Every Syrian woman must have access to affordable and accessible reproductive health care and be protected from gender-based violence that can occur at every stage of conflict," says Dr. Babatunde Osotimehin, Executive Director of UNFPA, the United Nations Population Fund, ahead of the Second International Humanitarian Pledging Conference for Syria, to take place this week in Kuwait. "As the number of Syrian women and girls of reproductive age is estimated to reach five million by the end of 2014, we count on the international community's support for UNFPA to continue to deliver lifesaving services to each and every one of them." - See more at: http://www.unfpa.org/public/home/news/ pid/15933\#sthash.YOkMScjK.dpuf/.

29 UNHCR. (2013). A Year in Review 2013 UNCHR Syria. Retrieved 19 June, 2014 from http://www.unhcr.org/52eb7a7a9. html.

30 No one shall be subjected to torture or to cruel, inhuman or degrading treatment or punishment (Article 5 of the Universal Declaration of Human Rights adopted by the General Assembly of UN on December 10, 1948). 
"For the purposes of this Convention the term 'torture' means any act by which severe pain or suffering, whether physical or mental, is intentionally inflicted on a person for such purposes as obtaining from him or a third person information or a confession, punishing him for an act he or a third person has committed or is suspected of having committed, or intimidating or coercing him or a third person, or for any reason based on discrimination of any kind, when such pain or suffering is inflicted by or at the instigation of or with the consent or acquiescence of a public official or other person acting in an official capacity. It does not include pain or suffering arising only from, inherent in or incidental to lawful sanctions" (Article 1, paragraph, Convention Against Torture and Other Cruel, Inhuman or Degrading Treatment or Punishment. The Convention was adopted and opened for signature, ratification and accession by General Assembly resolution 39/46 of 10 December 1984.)

31 The Universal Declaration of Human Rights. Article 16

(1) Men and women of full age, without any limitation due to race, nationality or religion, have the right to marry and to found a family. They are entitled to equal rights as to marriage, during marriage and at its dissolution.

Marriage shall be entered into only with the free and full consent of the intending spouses.

Retrieved 3 July, 2014 from http://www.un.org/en/documents/udhr/index.shtml\#a16.

32 Ahmad, Ali. (2013). Future Syrian Governments Must Address Women's Right to Equality. Retrieved 2 July, 2013 from http://www.damascusbureau.org/?p=4755.

33 UNHCR. (2013). A Year in Review 2013 UNCHR Syria. Retrieved 19 June, 2014 from http://www.unhcr.org/52eb7a7a9. html.

34 Fargues, P., \& Fandrich, C. (2014). The European Response to the Syrian Refugees Crisis What Next?. Retrieved 3 July, 2014 from http://www.migrationpolicycentre.eu/docs/MPC\%202012\%2014.pdf..

\title{
Война, насилие и женщины: на примере Сирийской гражданской войны (2013-2014)
}

\author{
Самина Нур \\ Исламский Университет Бахавалпура, \\ Пакистан
}

Некоторые страны имеют печальный опыт вооружённых конфликтов на своей территории, и это стало иентральной темой большинства исследований в сфере международньх отношений. Термин «гражданская война» стал повсеместно использоваться в качестве синонима вооружённого конфликта в мире. Третья по счёту гражданская война в Сирии унесла тысячи жизней и вынудила миллионы людей покинуть свои дома. Война - неизбежная реальность жестокой патриархальной системы, которая влечет за собой угнетение другой pacbl, нации и сексуальное насилие в отнотении женщин в качестве стратегической линии. Насилие в отношении женщин в Сирии выявило гендерные вопросы безопасности в рамках международных отношений. В данной статье анализируется насилие в отнотении женщин (VAW, violence against woтеn) в Сирии, затрагиваются проблемы безопасности, которые требуют рассмотрения и вмешательства. Гражданская война и насилие в отношении женщин не новы в современном мире, который мы считаем ичивилизованным. Как правило, женщины страдают во время вооружённых конфликтов больше всех. Изнасилования и жестокие убийства женщин во время вооружённого конфликта используются в качестве инструмента геноиида. В данной статье насилие над женщинами рассматривается на примере текущей Гражданской войны в Сирии.

Ключевые слова: гражданские войны, вооружённый конфликт, насилие в отнотении женщин (VAW, violence against women), международные отношения, изнасилование, Управление Верховного комиссара ООН по правам человека.

Научная специальность: 23.00.00 - политология. 